\title{
Application of Atomic Emission Spectrometry in Aviation Piston Engine Abnormal Wear Prevention
}

\author{
Dragana Prokić-Vidojević ${ }^{1)}$ \\ Zorica Živković1) \\ Olivera Barać ${ }^{1)}$
}

\begin{abstract}
The measurement of wear metals concentration in used lubricating oil can be used to determine whether an engine is approaching failure, allowing further damage to be avoided. In this paper the application of inductively coupled plasmaatomic emission spectrometry (ICP-OES) technique in prevention of abnormal wear of aviation piston engines is explained. Used oil samples taken from two different engines are analyzed in respect with the wear metals concentration using ICP-OES. Concentration level for each metal is plotted against time of flight and its changes are observed. It is shown that low metals levels and small concentrations changes are connected with the well lubricated surfaces, while sudden concentration increase is an indication of wear beginning. Factors affecting the wear quantification are also summarized.
\end{abstract}

Key words: aviation engine, piston engine, wear, engine oil, atomic emission spectrometry.

\section{Introduction}

$\mathrm{T}$ HE main function of lubricating oil in the engine is friction reduction between metal parts mating together. Therefore the wear rate of metal components is reduced. However, since continual wear occurs anyhow during the operation, wear debris remain in lubricating oil and circulate with it through the system. Lubricating oil analysis is fearly rapid and easy way to determine the engine contamination and wear [1]. Periodic oil sampling and analyzing during the engine exploitation allow data base formation for a normal wear rate monitoring, as well as abnormal wear diagnosis. Such analyses provide information of metal engine parts condition $[2,3]$.

The first worldwide spread application of this type of monitoring dates from 1940 when it was introduced by the American railway. By the middle 80s, spectroscopic engine oil analysis became a part of the engine condition monitoring program throughout USA $[4,5]$. Regarding this success, the American Air Forces implemented Spectrometric Oil Analysis Program (SOAP) in their regular turbine engine condition maintenance system.

In the Serbian Air Forces this way of monitoring started in a modest manner a decade ago, reaching its full expansion with inductively coupled plasma spectrometer implementation few years ago.

Fossil lubricating oils are petrol derivatives composed of paraffinic, naphthenic and aromatic hydrocarbons. In order to fulfill numerous functions in the engine, their performance is enhanced with the addition of different types of additives. Metal to metal contact can be suppressed by adding a film forming anti-wear additives, abrasive wear with air filtration and corrosion wear with alkaline detergents. Diverse processes, both physical and chemical, are a cause for engine wear. Physical wear occurs because of the friction between metallic parts, high working pressures and temperatures, abrasion caused by different contaminants from air. The main reason for chemical wear is corrosion caused by the acidic products formed during the exploitation. However, both wear types produce metal particles. They are both a consequence of wear as well as new damaging debris. Particle size distribution is wide $[1,6]$. Oil filter retains particles bigger than its porosity, while those smaller circulate through the system. Recording the key metals concentrations trend in used oil during the engine operation allow determination of normal wear rate concentrations and appropriate indications of abnormal wear of lubricated parts. For example, $\mathrm{Ni}, \mathrm{Sn}$ or $\mathrm{Cr}$ concentration increase indicate bearings, pistons or valves corrosion, $\mathrm{Al}$ indicates piston pin plugs wear, $\mathrm{Cu}$ bearings wear, Fe indicates corrosion of different parts, etc. [1].

Metal concentrations in used lubricants are mostly on the low levels connected with the well lubricated surfaces while normal wear rate, but during the exploitation they increase slowly [7]. Sudden sharp rise of some metal content or ever increasing concentration indicate an increased wear and, eventually, inappropriate engine work.

Conventional analytic techniques used for the oil monitoring are electroanalytical [8, 9], XRF (X-Ray Fluorescence Spectrometry) [10], those based on atomic spectrometry like FAAS (Flame Atomic Absorption Spectrometry) [11-16], ETAAS (Electro Thermal Atomic Absorption Spectrometry) [17], ICP OES [15, 16, 18-20] and ICP MS (Inductively Coupled Plasma Mass Spectrometry) $[16,21,22]$

The main goal of this paper is to present the application of inductively coupled plasma atomic emission spectromery in determination of the wear metals concentrations in used lubricating oil samples taken from two aviation piston engines in specified periods of flight and to present the way of using the obtained data in the engines wear monitoring. It will be shown how this kind of analysis can be useful in taking corrective

\footnotetext{
1) Military Technical Institute (VTI), Ratka Resanovića 1, 11132 Belgrade, SERBIA

Correspondence to: Dragana Prokić-Vidojević; e-mail: drprokic@yahoo.co.uk
} 
actions at the beginning of the wear process and prevent further wear increase through the preventive maintenance.

\section{Factors affecting wear quantification}

There are numerous factors that make quantitative engine wear monitoring very demanding. It must be pointed out that this kind of monitoring should not exclude other diagnostic techniques, like filter content inspection, differential cylinder pressure checks, borroscopic examination, etc.

Macian has already reviewed the majority of the factors influencing the wear quantification [23]. According to his findings, they can be divided in the following classes: the limits of technique used for wear quantification, the effects of exploitation conditions on the measured results and, finally, the performance of the particular engine (manufacturer, age, environment conditions, etc.).

\section{Analyzing technique limits}

Different wear types produce different particle size distribution. However, each spectrometry determination involves the particle size limitations. Inductively coupled plasma spectrometer has a $100 \%$ recovery for the particle size of maximum $5 \mu \mathrm{m}$. Therefore this limit should be taken into account when results analysis is done.

Apart from the aforementioned, the majority of advances of this technique make it by far the best wear analysis technique at the moment and the one most used. For more complicated cases, the results of these analyses are combined with the additional analysis, like particle counting, ferrografi, etc.

\section{Exploitation conditions}

\section{Oil consumption}

Quantification of the wear might be expressed like a concentration of a metal in an oil sample $(\mu \mathrm{g} / \mathrm{g})$. However, the concentration itself is affected by other factors, apart from the wear. Lubricant consumption during the exploitation is inevitable; therefore the lubricant has to be refilled periodically. The consequence of this consumption is wear metals concentrations increase, even though the wear rate remained constant. On the other hand, an addition of fresh lubricant causes decrease in the measured concentration. In a sufficient time period certain constant metals concentrations are reached [23].

\section{Filtering effect}

The important factor that influences the metals concentrations in lubricating oil is its filtration in the system. The contaminants quantity retained by the filters depends on the filter condition, as well as the particle size distribution and filter retention efficiency. Since spectrometry detects particles smaller than $5 \mu \mathrm{m}$, and filters retain more than $90 \%$ of particles bigger than $10 \mu \mathrm{m}$, therefore this effect can be neglected [23].

\section{Oil chemical composition}

Metallo-organic compounds can be added as additives in lubricants formulation. Therefore, it can be found that the same wear metal is present as additive in fresh lubricant. So, the fresh oil analysis is required in order to compensate current concentration.

\section{Method description}

Even though inductively coupled plasma is used for a long time for metal analysis in the water solutions, significant effort has been made in last decades to apply it to the organic solutions [22, 24-29]. American Society for Testing and Materials has developed the ASTM D5185 Method for Wear metals analysis in used lubricating oils using ICP-OES. The following analyses are done in accordance with ASTM D5185 [30].

Optical emission spectrometry with inductively coupled plasma source uses argon plasma energy for the sample atomization and excitation. Oil sample diluted in an organic solvent (mixed xylenes, kerosene, etc.) is nebulized into plasma. Sample evaporation, atomization, ionization, and excitation take place. The intensity of emitted light is measured. Each metal emits light in special wavelengths and those lines are used for a qualitative sample analysis. The emitted light intensity is proportional to the element concentration in lubricant and quantitative information is obtained. This technique has a low detection limit, wide dynamic concentration range and simultaneous and rapid determination of more than 20 elements.

\section{Experimental part}

In this paper the aviation piston engines wear monitoring is done, using the spectroscopic analysis of used engine oil sampled from aircraft each 10 hours of flight, after the run-in period preceding the overhaul, when the system is settled in. Commercial piston engine oil AeroShell W80, SAE grade 40 is used. Obtained concentration values are plotted against time of flight, and concentration trend is observed. Slight concentration changes indicate normal wear rate, while sudden rise alarms for increased wear beginnings.

The main engine parts are made of the aluminum pistons, steel or chrome cylinders, chrome plated or steel piston rings, aluminum or aluminum bronze piston pin plugs, etc. These parts are prone to wear during the operation, and their metal particles are deposited in lubricant.

Sampling of the used lubricant samples is made in accordance to the engine manufacturer service letter recommendation. The oil sampling is also done in accordance with the engine manufacturer service letter recommendation. Fresh oil analysis of the wear metals is done, as well.

\section{Apparatus}

All analyses are performed on Spectro Genesis Inductively Coupled Plasma Optical Emission Spectrometer, with a radial viewing. With 15 linearly positioned CCD detectors, wavelengths range from 175 to $777 \mathrm{~nm}$ can be measured. Burgener nebulizer and cyclonic spray chamber are used. Working parameters are listed in Table 1 .

Table 1. Operating parameters

\begin{tabular}{||c|c||}
\hline Plasma Power & $1450 \mathrm{~W}$ \\
\hline Coolant flow & $14 \mathrm{~L} / \mathrm{min}$ \\
\hline Auxiliary flow & $1.8 \mathrm{~L} / \mathrm{min}$ \\
\hline Nebulizer flow & $0.7 \mathrm{~L} / \mathrm{min}$ \\
\hline Spray Chamber & Cyclonic Type \\
\hline Nebulizer & Burgener type \\
\hline Pump tubing & $\begin{array}{c}\text { Orange/orange for sample } \\
\text { Grey/grey for drain }\end{array}$ \\
\hline
\end{tabular}

\section{Wear metals and wavelengths selection}

Wear metals are chosen in accordance with the information about alloys composition used for the engine parts. Silicon is usually an indication of air dust contamination, so its concentration is also measured. The following elements are measured: $\mathrm{Al}, \mathrm{Cr}, \mathrm{Cu}, \mathrm{Fe}, \mathrm{Sn}, \mathrm{Si}$. Wavelengths are chosen taking into account the spectral interferences and are listed in Table 2. 
Table 2. Selected wavelengths

\begin{tabular}{|c|c|}
\hline \hline Element & Wavelength, nm \\
\hline \hline $\mathrm{Al}$ & 396.15 \\
\hline $\mathrm{Cr}$ & 267.71 \\
\hline $\mathrm{Cu}$ & 327.40 \\
\hline $\mathrm{Fe}$ & 238.20 \\
\hline $\mathrm{Sn}$ & 189.99 \\
\hline $\mathrm{Si}$ & 251.61 \\
\hline
\end{tabular}

\section{Calibration standards and calibration}

For calibration purposes, certified reference materials, organic standards, are used:

1. Multi-element metallo-organic oil standard with 23 elements, V23 Wear Metals, LGC Standards, VHG Labs, $10 \mu \mathrm{g} / \mathrm{g}, 50 \mu \mathrm{g} / \mathrm{g}, 100 \mu \mathrm{g} / \mathrm{g}$;

2. Base oil Blank $75 \mathrm{~mm}^{2} / \mathrm{s}$, LGC Standards, VHG Labs;

3. Internal oil standard, Co, $5000 \mu \mathrm{g} / \mathrm{g}$, LGC Standards, VHG Labs;

4. Dilution solvent, V-SOLV TM ICP Solvent, LGC Standards, VHG Labs;

5. Multi-element metallo-organic standard of aviation oil with 19 elements, D19 Standard $10 \mu \mathrm{g} / \mathrm{g}$; LGC Standards, VHG Labs;

Calibration standards of different concentrations are prepared by diluting the aforementioned metallo-organic standards in ICP solvent, $10 \% \mathrm{~m} / \mathrm{m}$. Cobalt solution is used as an internal standard. Internal standard is added in order to compensate for differences in viscosity and volatility of the samples and calibration standards. For a blank sample, base oil is dissolved in ICP solvent.

Calibration standards concentrations, correlation coefficients and detection limits are given in Table 3 and Table 4, respectively.

Multi-element aviation oil solution is used as a check standard during the analysis. The precision and accuracy of the measurements are given in Table 5.

Table 3. Calibration standards concentration

\begin{tabular}{||c|c|c|c|c||}
\hline Element & $\begin{array}{c}\text { CS 1, } \\
\mu \mathrm{g} / \mathrm{g}\end{array}$ & $\begin{array}{c}\text { CS 5, } \\
\mu \mathrm{g} / \mathrm{g}\end{array}$ & $\mathrm{CS} 10, \mu \mathrm{g} / \mathrm{g}$ & $\mathrm{CS} 20, \mu \mathrm{g} / \mathrm{g}$ \\
\hline $\mathrm{ynnnn} \mathrm{Al}$ & & & & \\
\cline { 1 - 1 } $\mathrm{Cr}$ & \multirow{2}{*}{1.01} & 4.99 & 9.99 & 20.06 \\
\cline { 1 - 1 } $\mathrm{Cu}$ & & & & \\
\cline { 1 - 2 } $\mathrm{Se}$ & & & & \\
\cline { 1 - 2 } $\mathrm{Si}$ & & & & \\
\hline
\end{tabular}

Table 4: Regression correlation coefficients and detection limits

\begin{tabular}{|c|c|c||}
\hline Element & Correlation coefficient & $\begin{array}{c}\text { Detection limit (LOD), } \\
\mu \mathrm{g} / \mathrm{g}\end{array}$ \\
\hline \hline $\mathrm{Al}$ & 0.99988 & 0.0085 \\
\hline $\mathrm{Cr}$ & 0.99996 & 0.0072 \\
\hline $\mathrm{Cu}$ & 0.99998 & 0.0107 \\
\hline $\mathrm{Fe}$ & 0.99999 & 0.0063 \\
\hline $\mathrm{Sn}$ & 1.00000 & 0.0371 \\
\hline $\mathrm{Si}$ & 0.99999 & 0.0298 \\
\hline
\end{tabular}

Table 5. Precision (RSD) and accuracy (Bias) of the check standard measurements

\begin{tabular}{|c|c|c|}
\hline Element & RSD, $\%$ & Bias, $\%$ \\
\hline \hline $\mathrm{Al}$ & 1.9 & 1.2 \\
\hline $\mathrm{Cr}$ & 2.2 & 1.3 \\
\hline $\mathrm{Cu}$ & 1.5 & 0.9 \\
\hline $\mathrm{Fe}$ & 2.9 & 1.0 \\
\hline $\mathrm{Sn}$ & 2.5 & 1.1 \\
\hline $\mathrm{Si}$ & 3.0 & 2.2 \\
\hline
\end{tabular}

\section{Samples preparation}

Used oil samples are taken following the engine manufacturer instructions every 10 hours of flight. Appropriate homogenization of used oil sample is an important step in preparation for the analysis. This is done using the automatic homogenizer for half an hour (labs personnel experience with this type of homogenizer and the sample material). A sample portion of $2 \mathrm{~g}$ is then diluted with dilution solvent to $20 \mathrm{~g}$. Two probes of each sample are prepared. The result is the mean value of three instrument readings. The final result is the mean value of two probes samples. Before and after the samples measurements, the control standards are measured.

\section{Results and discussion}

The results for the piston engine 1 (APE-1) and 2 (APE-2) are presented in Table 6 and Table 7, respectively. Concentrations levels vs. time of flight for the piston engine 1 and 2 are presented in Figures 1 and 2, respectively. Used oil analysis from the aviation piston engine APE-1 shows that the concentration level of wear metals can be divided into two levels: element which concentration is above $10 \mu \mathrm{g} / \mathrm{g}$ constantly, and those elements present in concentrations below $10 \mu \mathrm{g} / \mathrm{g}$.

Iron belongs to the first mentioned group. Such a result is expected, since the wear sources for iron are numerous. Their cumulative value is measured concentration, and therefore the most difficult element to locate in case of the abnormal wear. The limit value considered as a "normal wear" is $100 \mu \mathrm{g} / \mathrm{g}$ (the value given by the engine manufacturer, table 8 ). The average value measured in the samples from APE-1 for 130 hours of flight is around $10 \mu \mathrm{g} / \mathrm{g}$. Since these measurements are done long enough after the overhaul, when the run-in period is elapsed and the engine is settled in, very low wear rate is observed.

The second element group involves the following metals: copper, chrome and aluminum. Their concentrations do not increase above $5 \mu \mathrm{g} / \mathrm{g}$ while normal wear. They have some slight fluctuations from 0.20 to $2.20 \mu \mathrm{g} / \mathrm{g}$, without obvious rising trend. The limit values for normal wear rate for these metals are given in Table 8 .

Table 8. Normal wear limit values given by the engine manufacturer

\begin{tabular}{|c|c|}
\hline Element & Limit values, $\mu \mathrm{g} / \mathrm{g}$ \\
\hline \hline $\mathrm{Fe}$ & 100 \\
\hline $\mathrm{Cu}$ & 10 \\
\hline $\mathrm{Cr}$ & 50 \\
\hline $\mathrm{Al}$ & 20 \\
\hline $\mathrm{Si}$ & 10 \\
\hline
\end{tabular}

Fig.1 indicates the following: sudden $\mathrm{Si}$ concentration increase in the sample number 2 , from 3.7 to $23.8 \mu \mathrm{g} / \mathrm{g}$ is probably triggered by the contaminants (dust and sand) ingested with air during the engine operation. Consequently, slight rise of $\mathrm{Cr}$ and $\mathrm{Fe}$ concentration is noticed in the same sample, most likely caused by the abrasive contaminants wear. These results show eventual beginning of rings and cylinders increased wear, the engine parts made of these metals alloys. In order to prevent further wear propagation, corrective filter replacement, and therefore better contaminants retainment, quickly resulted in decreased silicon content below the limit value in the next sample, number 3, and prevention of further iron and chrome content increase. The following samples (number 4, 5 and 6) analyses show constant concentration level of copper, chrome and aluminum, with values less than $1.5 \mu \mathrm{g} / \mathrm{g}$. At the same time, iron content 
is at $10 \mu \mathrm{g} / \mathrm{g}$. These values are inside the normal wear rate limits, and such steady concentrations levels in this operation period is a sign of no serious wear. In the samples number 6 and 7 iron content is still rising, along with the increase of silicon, copper and aluminum concentrations in the sample 7 . This is an indication of the beginnings of aluminum alloys engine parts wear (pistons and piston pin plugs), caused again with dirt ingestion (Si rise). Subsequent filter change resulted in silicon decrease in the next sample, better dust and sand retainement, and sudden concentration decrease of all other four measured metals. This is evident from the analysis of the sample number 8 . The following results show normal wear rate trend, with copper, chrome, iron and aluminum concentrations inside the acceptable limits for used oil. Silicon content increase is again evident starting from the sample number 8 until the sample number 12 , followed by a sudden iron rise in the sample number 12. Corrective action taken immediately, the third filter replacement, prevented further increase of the engine wear.

Table 5. Engine APE-1: used engine oil analyses every 10 hours of flight

\begin{tabular}{|c|c|c|c|c|c|c||}
\hline $\begin{array}{c}\text { Sample } \\
\text { number }\end{array}$ & $\begin{array}{c}\text { Hours of } \\
\text { flight }\end{array}$ & $\begin{array}{c}\mathrm{Fe} \\
\mu \mathrm{g} / \mathrm{g}\end{array}$ & $\begin{array}{c}\mathrm{Cu} \\
\mu \mathrm{g} / \mathrm{g}\end{array}$ & $\begin{array}{c}\mathrm{Cr} \\
\mu \mathrm{g} / \mathrm{g}\end{array}$ & $\begin{array}{c}\mathrm{Al} \\
\mu \mathrm{g} / \mathrm{g}\end{array}$ & $\begin{array}{c}\mathrm{Si} \\
\mu \mathrm{g} / \mathrm{g}\end{array}$ \\
\hline \hline 0 & Fresh oil & $<\mathrm{LOD}$ & $<\mathrm{LOD}$ & $<\mathrm{LOD}$ & $<\mathrm{LOD}$ & $<\mathrm{LOD}$ \\
\hline 1 & 10 & 6.91 & 1.30 & 0.60 & 0.32 & 3.70 \\
\hline 2 & 20 & 9.62 & 1.90 & 1.41 & 0.21 & 23.81 \\
\hline \multicolumn{7}{|c|}{ Filter replacement } \\
\hline 3 & 30 & 7.52 & 1.01 & 1.21 & 1.02 & 5.11 \\
\hline 4 & 40 & 5.21 & 0.81 & 0.52 & 0.11 & 3.22 \\
\hline 5 & 50 & 9.83 & 0.52 & 1.02 & 0.90 & 3.21 \\
\hline 6 & 60 & 12.41 & 0.61 & 1.33 & 1.32 & 3.43 \\
\hline 7 & 70 & 13.61 & 1.32 & 1.43 & 2.21 & 5.62 \\
\hline \multicolumn{7}{|c|}{ Filter replacement } \\
\hline 8 & 80 & 8.00 & 0.54 & 0.81 & 0.73 & 1.51 \\
\hline 9 & 90 & 7.60 & 0.71 & 0.82 & 1.01 & 2.31 \\
\hline 10 & 100 & 7.41 & 0.31 & 0.64 & 0.87 & 4.22 \\
\hline 11 & 110 & 7.51 & 0.42 & 0.80 & 1.21 & 5.21 \\
\hline 12 & 120 & 28.81 & 0.72 & 1.02 & 1.52 & 4.32 \\
\hline \multicolumn{7}{|c|}{ Filter replacement } \\
\hline 13 & 130 & 8.03 & 0.52 & 0.61 & 0.52 & 2.61 \\
\hline
\end{tabular}

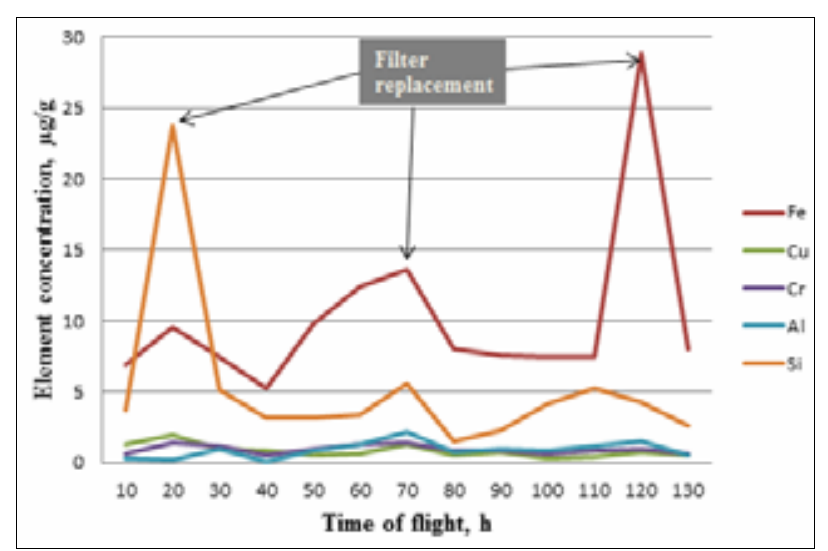

Figure 1. Engine APE-1: Elements concentration every 10 hours of flight

Used oil analysis from the aviation piston engine APE-2 reveal constant "normal wear" rate, showing slight fluctuation of the concentration levels in oil samples during time. All four metals concentrations (without $\mathrm{Si}$ ) are inside the normal wear limits for used oil. Also, in this engine, the iron content is around $10 \mu \mathrm{g} / \mathrm{g}$ in samples. Except in the case of sample number 8 , copper, chrome and aluminum do not rise above 5 $\mu \mathrm{g} / \mathrm{g}$, as well. This steady trend is associated with the satisfactory lubrication of metal parts. However, the analysis of the sample number 8 shows sharp rise of aluminum content, from 1.9 to $7.5 \mu \mathrm{g} / \mathrm{g}$, simultaneously with iron and silicon rise. This abrupt escalation indicates that the wear process takes place. That was the alarm for the subsequent engine inspection, necessary for increased wear confirmation and failure prevention. This shows how sudden wear can occur in one stable system, and how it results in concentration levels changes.

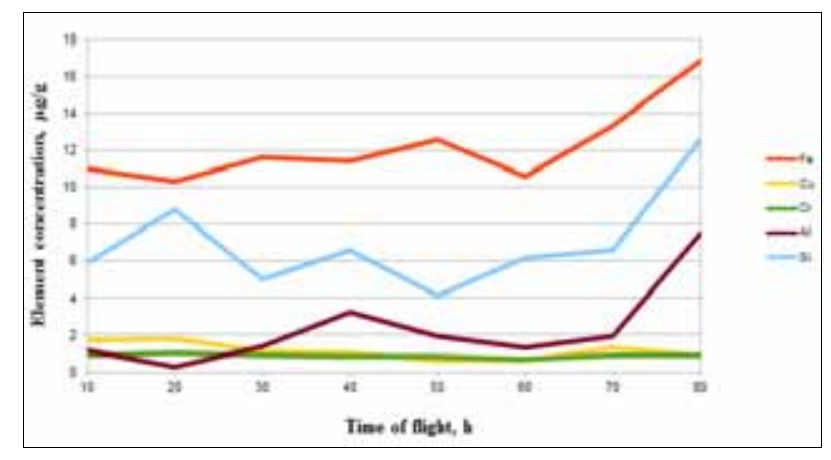

Figure 2. Engine APE-2: Elements concentration every 10 hours of flight

Table 6: Engine APE-2: used engine oil analyses every 10 hours of flight

\begin{tabular}{||c|c|c|c|c|c|c||}
\hline $\begin{array}{c}\text { Sample } \\
\text { number }\end{array}$ & $\begin{array}{c}\text { Hours } \\
\text { of flight }\end{array}$ & $\begin{array}{c}\mathrm{Fe} \\
\mu \mathrm{g} / \mathrm{g}\end{array}$ & $\begin{array}{c}\mathrm{Cu} \\
\mu \mathrm{g} / \mathrm{g}\end{array}$ & $\begin{array}{c}\mathrm{Cr} \\
\mu \mathrm{g} / \mathrm{g}\end{array}$ & $\begin{array}{c}\mathrm{Al} \\
\mu \mathrm{g} / \mathrm{g}\end{array}$ & $\begin{array}{c}\mathrm{Si} \\
\mu \mathrm{g} / \mathrm{g}\end{array}$ \\
\hline \hline 0 & Fresh oil & $<\mathrm{LOD}$ & $<\mathrm{LOD}$ & $<\mathrm{LOD}$ & $<\mathrm{LOD}$ & $<\mathrm{LOD}$ \\
\hline 1 & 10 & 11.01 & 1.70 & 0.92 & 1.20 & 5.92 \\
\hline 2 & 20 & 10.32 & 1.81 & 1.20 & 0.32 & 8.81 \\
\hline 3 & 30 & 11.61 & 1.12 & 0.91 & 1.41 & 5.12 \\
\hline 4 & 40 & 11.44 & 1.11 & 0.81 & 3.22 & 6.61 \\
\hline 5 & 50 & 12.63 & 0.63 & 0.82 & 1.92 & 4.12 \\
\hline 6 & 60 & 10.62 & 0.61 & 0.73 & 1.31 & 6.22 \\
\hline 7 & 70 & 13.32 & 1.31 & 0.91 & 1.91 & 6.61 \\
\hline 8 & 80 & 16.81 & 0.92 & 0.92 & 7.53 & 12.63 \\
\hline
\end{tabular}

\section{Concluding remarks}

In this paper the application of inductively coupled plasma atomic emission spectroscopy as a useful tool for the aviation piston engines condition monitoring is described. Also, spectrometry technique limits and advantages are summarized. Discussing results of used engine oils taken in specified time of flight intervals from two different engines, it is explained how the wear metals and contaminants concentrations trends and changes can reveal engine contamination and wear beginning. It is also shown that taking corrective actions at the very beginning of the wear process further wear propagation can be suppressed. Therefore, this is a useful tool in predictive maintenance, especially for aviation engines, where any failure can be fatal.

\section{Reference}

[1] ROYLANCE, B.J., HUNT,T.M.: Wear Debris Analysis (Coxmoor's Machine \& Systems ConditionMonitoring), ISBN 1901892026 , Coxmoor Publishing Company, UK, 1999.

[2] TROYER,D., FITCH,J.: Oil Analysis Basics, Noria Corporation, 2001.

[3] DENIS,G., BRIANT,H., HIPEAUX,B.: Lubricant Properties Analysis and Testing, Editions TECHNIP, 2000.

[4] EVANS,J.S.: Oil Analysis Handbook (Coxmoor's Machine \& Systems Condition Monitoring), Coxmoor Publishing Company, UK, 2008.

[5] FITCH,J.: Source Book for Used Oil Elements, Noria Corporation, 2001.

[6] Mc ELROY,F., MENNITO,A., DEBRAH,E., THOMAS,R.: Uses and applications of inductively coupled plasma mass spectrometry in the petrochemical industry, Spectroscopy, 1998, Vol.13, pp. 42-53.

[7] PAWLAC,Z:: Tribochemistry of Lubricating Oils, ISBN 978-0-44451296-3, Elsevir Science, 2003.

[8] MUNOZ,R.A.A., ANGES,L.: Simultaneous determination of copper and lead in ethanol fuel by anodic stripping voltammetry, Microchem. J., 2004, Vol.77, pp. 157-162. 
[9] MUNOZ,R.A.A., SILVA,C.S., OLIVEIRA,P.V., ANGNES,L.: Potentiometric stripping analysis for simultaneous determination of copper and lead in lubricating oils after total digestion in a focused microwave-assisted oven, Microchim. Acta, 2005, Vol.149, pp. 199204.

[10] POUZAR,M., CERNOHORSKY,T., KREJOOVA,A.: Determination of metals in lubricating oils by X-ray fluorescence spectrometry, Talanta, 2001, Vol.54, pp. 829-835.

[11] [11]DUYCK,C., MIEKELEY,N., da SILVEIRA,C.L.P., AUCELIO,R.Q., CAMPOS,R.C., GRINBERG,P., BRANDAO,G.P.: The determination of trace elements in crude oil and its heavy fractions by atomic spectrometry, Spectrochim. Acta B At. Spectrosc., 2007., Vol. 62, pp. 939-951.

[12] AMORIM,F.A.C., WELZ,B., COSTA,A.C.S., LEPRIC,F.G, VALE,M.G.R, FERREIRA,S.L.C.: Determination of vanadium in petroleum and petroleum products using atomic spectrometric techniques, Talanta, 2007., Vol.72, pp. 349-359.

[13] BERNDT,H., SCHALDACH,G., KAGLER,S.H.: Flame AAS/flame AES for trace determination in fresh and used lubricating oils with sample introduction by hydraulic high-pressure nebulization, Fresenius J. Anal. Chem., 1996, Vol. 335, pp. 37-42.

[14] MORA,J., TODOLI,J.: Determination of metals in lubricating oils by flame atomic absorption spectrometry using a single-bore highpressure pneumatic nebulizer, Analyst, 2000, Vol. 125, pp. 2344-2349.

[15] VAHAOJA,P., VALIMAKI,I., HEINO,K., PERAMAKI,P., KUOKKANEN,T.: Determination of wear metals in lubrication oils: $a$ comparison study of ICP-OES and FAAS, Anal. Sci., 2005, Vol.21, pp. $1365-1369$.

[16] AUCELIO,R.Q., MATINEZ de SOUZA, CALIXTO de CAMPOS, R.R., MIEKELEY, N., PPRTO da SILVEIRA, C. L.: The determination of trace metals in lubricating oils by atomic spectrometry, Spec. Acta Part B, 2007, Vol.62, pp. 952-961

[17] BRANDAO, G.P., de CAMPOS, R.C., de CASTRO,E.V.R., de JESUS,H.C.: Determination of copper, iron and vanadium in petroleum by direct sampling electrothermal atomic absorption spectrometry, Spectrochim. Acta B At. Spectrosc., 2007, Vol. 62, pp. 962-969.

[18] SANCHEZ,R., TODOLI,J.L, LIENEMANN,C.P., MERMET,J.M.: Effect of solvent dilution on the ICP-AES based silicon sensitivity, the aerosol characteristics and the resulting organic solution properties in the analysis of petroleum products, J. Anal. At. Spectrom.2010., Vol.25,pp. 178-185.

[19] SANCHEZ,R., TODOLI,J.L, LIENEMANN,C.P., MERMET,J.M. Minimization of the effect of silicon chemical form in xylene matrices on ICP-AES performance, J. Anal. At. Spectrom, 2009., Vol.24, pp. $1382-1388$.

[20] SOUZA,R.M., MELIANDE,A.L.S, SILVEIRA,C.L.P., AUCELIO,R.Q.: Determination of Mo, $\mathrm{Zn}, \mathrm{Cd}, \mathrm{Ti}, \mathrm{Ni}, \mathrm{V}, \mathrm{Fe}, \mathrm{Mn}, \mathrm{Cr}$ and Co in crude oil using inductively coupled plasma optical emission spectrometry and sample introduction as detergentless microemulsions, Microchem. J., 2006, Vol. 82, pp. 137-141.

[21] CAUMETTE,G., LIENEMANN,C.P., MERDRIGNAC,I., PAUCOT,H., BOUYSSIERE,B., LOBINSKI,R.: Sensitivity improvement in ICP MS analysis of fuels and light petroleum matrices using a microflow nebulizer and heated spray chamber sample introduction, Talanta, 2009, Vol. 80, pp. 1039-1043.

[22] PASZEK,J., MASON,K.J., MENNITO,A.S., McELROY,F.C.: Advances in ICP-MS technologies for characterization and ultra-trace speciation as a tool for the petroleum industry, Elem. Anal. of Fuels and Lubricants: Recent Advances and Future Prospects, 2005., Vol.1468, pp. 42-50.

[23] MACIAN,V., TORMOS,B., OLMEDA,P., MONTORO,L., Analytical approach to wear rate determination for internal combustion engine condition monitoring based on oil analysis, Trib. Inter., 2003, Vol.36, pp. 771-776.

[24] SANCHEZ,R., TODOLI,J.L, LIENEMANN,C.P., MERMET,J.M.: Determination of trace elements in petroleum products by inductively coupled plasma techniques: A critical review, Spectrochim. Acta Part B, 2013, Vol.88, pp. 104-126.

[25] LIENEMANN, C.P., DREYFUS, S., PECHEYRAN, C., DONARD, O.F.X.: Trace metal analysis in petroleum products: sample introduction evaluation in ICP-OES and comparison with an ICP-MS approach, Oil Gas Sci. Technol. Rev. Inst. Francais Petrol., 2007, Vol.62, pp. 69-77.

[26] SANCHEZ,R., TODOLI,J.L, LIENEMANN,C.P., MERMET,J.M.: Universal calibration for metal determination in fuels and biofuels by inductively coupled plasma atomic emission spectrometry based on segmented flow injection and $a 350^{\circ} \mathrm{C}$ heated chamber, J. Anal. At. Spectrom., 2012, Vol.27, pp. 937-945.

[27] RYAN,A., Multi-element Analysis of Fuel \& Lubricating Oils by Simultaneous ICP-AES, Varian, ICP-27, 1999.

[28] KUOKKANEN,T., PERAMAKI,P., VALIMAKI,I., RONNKOMAKI, H.: Determination of heavy metals in waste lubricating oils by inductively coupled plasma-optical emission spectrometry, Intern. J. Anal. Chem., 2001, Vol.81, pp. 89-99.

[29] JANSEN,E.B.M., KNIPSCHEER,J.H., NAGTEGAAL,M.: Rapid and accurate element determination in lubricating oils using inductively coupled plasma optical emission spectrometry, J. Anal. At. Spectrom., 1992, Vol.7, pp. 127-130.

[30] Standard Test Method for Multielement Determination of Used and Unused Lubricating Oils and Base Oils by Inductively Coupled Plasma Atomic Emission Spectrometry (ICP-AES), ASTM D5185, ASTM, 2013.

Received: 12.01.2016. Accepted: 16.03.2016.

\title{
Primena atomske emisione spektrometrije u prevenciji habanja avionskih klipnih motora
}

\begin{abstract}
Merenje koncentracije metala habanja u korišćenom ulju za podmazivanje motora može biti dobar pokazatelj da li je blizu otkaz rada motora, omogućavajući da se pravovremenom reakcijom izbegnu krupnija oštećenja vitalnih delova motora. $U$ ovom radu je prikazana primena tehnike indukovane kuplovane plazme-atomske emisione spektrometrije (ICP-OES) u prevenciji pojačanog habanja avionskih klipnih motora. Analizirani su uzorci korišćenog ulja za podmazivanje na sadržaj metala habanja iz dva avionska motora, korišćenjem ICP-OES. Grafički je predstavljena koncentracija svakog pojedinačnog metala habanja zavisno od vremena leta aviona i praćene su promene koncentracije. Pokazano je da je nagli skok koncentracije metala indikacija početaka habanja, dok je niska vrednost iste pokazatelj dobro podmazanih površina. Predstavljeni su faktori koji utiču na kvantifikaciju habanja.
\end{abstract}

Ključne reči: avionski motor, klipni motor, habanje, motorno ulje, atomska emisiona spektrometrija. 


\title{
Применение атомно-эмиссионной спектрометрии в предотвращении износа авиационных поршневых двигателей
}

\begin{abstract}
Измерение концентрации износа металлов в отработанном масле для смазки двигателя может быть хорошим индикатором того, является ли вблизи отказ и отмена двигателя, что позволяет своевременно реагировать, чтобы избежать большего повреждения жизненноважных деталей двигателя. В данной работе показан метод получения индуцированной связанной плазмой атомно-эмиссионной спектрометрии (ICP-OES) для предотвращения чрезмерного износа поршневых авиационных двигателей. Анализированы образцы использованного смазочного масла на содержание износа металлов из двух авиационных двигателей, с использованием ICP-OES. Графически представлена концентрация износа каждого металла в зависимости от времени работы - полёта самолёта, и здесь сопровождаются изменения в концентрации. Здесь показано, что внезапное увеличение концентрации металла-это индикация зачатков износа, в то время как низкое значение концентрации - показатель хорошо смазанной поверхности. Тоже представлены рекомендуемые факторы, влияющие на количественную оценку износа.
\end{abstract}

Ключевые слова: авиационный двигатель, поршневой двигатель, износ, моторное масло, атомно-эмиссионная спектрометрия.

\section{Application de la spectrométrie émissive dans la prévention de l'usure des moteurs d'avion à piston}

\begin{abstract}
Le mesurage de l'usure de métal dans l'huile de graissage usée des moteurs peut être un bon indicateur si la défaillance du moteur est proche et cela permet de réagir à temps pour éviter les endommagements considérables chez les patries vitales de moteur. Dans ce travail on présente l'application de la technique de plasma induit couplé-spectrométrie atomique émissive (ICP-OES) dans la prévention de l'usure rapide des moteurs d'avions à piston. On a analysé les échantillons de l'huile utilisée de graissage à l'égard du contenu du métal d'usure chez deux moteurs d'avion en appliquant la technique ICP-OES. On a présenté graphiquement la concentration de chaque métal particulier par rapport au temps de vol d'avion et on a observé les changements des concentration. On a démontré que l'augmentation rapide de la concentration de métal indique le début de l'usure alors que la basse valeur de concentration indique les surfaces bien huilées. On a présenté aussi les facteurs influents sur la quantification de l'usure.
\end{abstract}

Mots clés: moteur d'avion, moteur à piston, usure, huile de graissage, spectrométrie atomique émissive. 